picked too small an issue on which to fight. It is a much more serious threat that the sense of parsimony now settling on the universities may put a stop to developments in university teaching which are essential if British universities are to remain respectable in the years ahead. It is particularly important that the need of more postgraduate teaching, recognized by Robbins, should now be translated into fact. There are plenty of opportunities, expensive in the immediate future but economical in the long run, for collaboration between groups of universities well placed geographically. There is a great and universal need to make experiments with new kinds of teaching equipment. It is vital that universities, or those universities which feel so inclined, should be free to make experiments with undergraduate courses lasting four years coupled with less stringent requirements of students on entry. The most immediate danger is that the coincidence of renewed financial pressure from the Treasury and the attainment of the Robbins goal will bring in a period of stagnation in British universities. To demonstrate that such an outcome would be disastrous is more important than paying bills on time. After all, it is always possible for universities to borrow from the banks.

\section{BURN MORE COAL}

THE Minister of Power is not planning to produce a comprehensive statement of British fuel policy before the autumn, but its broad outlines were plainly to be seen in the long and repetitive debate on the coal industry which spanned Tuesday and Wednesday in the Commons this week. Briefly, Mr Richard Marsh has gone further than most of his predecessors to acknowledge that the decline of the British coal industry, which has been continuous for the past decade, will persist for several decades to come. But, like his predecessors, Mr Marsh has chosen to take the edge off some of the problems which need solving by providing further measures of protection for the coal industry. Against their better economic judgment, the electricity and gas industries are to be asked to burn an extra six million tons of coal a year between now and 1971, and the British Government is to subsidize them for doing so. The fact that the minister is planning to do more than his predecessors to tackle directly the social problems of a declining coal industry will not entirely make palatable this dubious decision.

A plain recognition of what is happening to coal is nevertheless a considerable public asset, even though the trends have been plain ever since the mid-fifties, when the potential economic advantages of nuclear power first became apparent. Then the annual production of coal from British mines amounted to more than 200 million tons in each of several consecutive years, and there were plenty of people willing to burn the coal. Although electricity generating stations were the largest single customer, their collective consumption was hardly more than 12 or 15 per cent of all the coal produced in Britain. Since then, however, events have moved rapidly to the disadvantage of the coal industry. The most serious and persistent influence has been the high cost of mining coal from British coal seams. The immediate result has been enormously to stimulate the growth of petroleum consumption in Britain. In spite of various measures of discrimination against petroleum which are equivalent in aggregate to a tax of something like 40 per cent, it is an open secret now openly acknowledged by the minister that the electricity generating industry would have preferred to substitute oil for coal at several modern power stations. But coal has also in recent years been able to shelter behind a ban on imports of cheaper coal from overseas and a ready supply of capital from public funds. It is no wonder that Lord Robens has been exuding sweetness and light in the past few weeks, for even he cannot have been entirely sure that yet another brake on the decline of his industry would be provided. The result-or at least the hope-is that by 1971 the annual consumption of coal in Britain will amount to 155 million tons, and that the nationalized secondary fuel industries-electricity and gas-will consume well over half of everything produced.

Protection as such, of course, is not entirely outrageous, and governments are frequently justified in shielding new and potentially important industries from competition which may be too fierce for survival. But the protection of declining industries is more often a snare than an economic benefit-the attempts to keep the British cotton industry on its feet in the decades since the war are a vivid illustration of that. With coal, the evil consequence of too much protection is likely to be an inflated price structure throughout the fuel economy. Tronically, Mr Marsh will probably find this out for himself when he is required in the next few weeks to adjudicate on the price to be paid by the Gas Council for North Sea gas. His freedom to fight hard for a low price will be compromised, to say the least of it, by his readiness to support the domestic market at too high a level. At the same time he may find that he has artificially unbalanced the development of nuclear reactors in the critical years immediately ahead. The British nuclear power industrywhich does not deserve protection even though the economic case for it is stronger than with coal-now needs a steady flow of orders on which to cut its teeth and firm incentives to keep costs low enough to be able to compete successfully abroad. By asking the power stations to burn more coal than they want to, the Government has probably done more harm than good.

It is entirely possible, of course, that further measures of protection are not a kindness for the communities which depend on coal, but merely a means of providing them with a false sense of security. For what is to happen after 1970? Will the British Government then be prepared to maintain an artificial level of demand for coal ? And if not, will there be a sudden contraction of the industry? In the early seventies 
it is entirely possible that the natural demand for coal could be more like 100 million tons a year than the 155 million tons now planned for. The traditional customers are melting away. In a few years there will be a demand for 70 million tons or so of coal each year from power stations now working or being built, a demand for 20 million tons or so of coking coal each year for making steel, and the rump of that traditional but anachronistic market for coal to be burnt on open hearths in people's houses. But who else will want to burn coal ? And who else will be able to afford to do so ? In all the circumstances, it might have been safer and in the long run kinder to the men concerned if the Government had sought to anticipate the changes which are now well under way and not to delay them. It would have made more sense to aim at a contraction from the present rate of production of 164 million tons a year to something more like 140 million tons a year or even less by the end of the decade, and then to have done whatever may be necessary to see that people and communities robbed of work are given other things to do.

\section{UNLUCKY S'TRIKE}

Columbia UnIversity seems to have made a serious error of judgment in its decision to undertake the management of a new cigarette filter. Even if the filter turns out to be as effective in removing tar and other condensates from cigarette smoke as its inventor, Dr Robert Strickman, claims, the university will have some tedious explanation to provide. It is therefore important to be quite clear that nobody objects-or should object-to the university making money. The independent universities in the United States are respected as well as envied by similar institutions elsewhere. The way in which they are able to live by their own laws must naturally seem a great opportunity to others less favourably placed. The fact that they have chosen to devote so much of their resources to creative scholarship is a striking proof of their highmindedness. In the last resort, their freedom is based on their financial independence. Yet there are some ways in which universities, however great, cannot live by the simple rules which govern commercial enterprises. There are some kinds of money which they should not make, and there are some ways of making money which they should avoid. Some of this seems to have been forgotten in all the ballyhoo attending the launching of the new filter on July 13.

In the first place, it is entirely mystifying that the university should have taken such trouble to make a great occasion out of its public announcement that Dr Strickman had been generous enough to transfer to the university most (though not all) of his rights in the new filter. Columbia knows enough about the ways in which newspapers work to know that it is almost impossible to hint that an important announcement on smoking and health is on the way without whipping up excitement. In the event, trading in tobacco shares on the New York Stock Exchange was stopped between midday and the point later in the afternoon at which stockbrokers could inform themselves about the news which Columbia had to broadcast.

And that, of course, was a bitter disappointment. As yet, there is only the most sketchy information about what the filter may accomplish. At Columbia on July 13, both the President, Dr Houston Kirk, and Dr Strickman steadfastly declined to say what the new filter is made of, or how its supposed effectiveness has been demonstrated. With so little to say, it is unlikely that an ordinary commercial company would have been able to create quite such a sensation. Indeed, announcements of improved filters are frequently to be heard. When the New York Stock Exchange stopped trading in tobacco, that was as much a measure of respect for the university as a proof of the statement that the new filter "is 70 per cent more effective" in removing tar from tobacco than other filters now on the market. And in any case, of course, whatever tests there may have been in Dr Strickman's laboratory, it is exceedingly improbable that anybody has had time to carry out clinical tests of the extent, if any, to which the new filter can diminish the incidence of lung cancer.

But should a great university rely on income from tobacco smoking? This is one of the questions now to be asked. Perhaps the first, though the most trivial, thing to say is that the Chancellor of the Exchequer in Britain would immediately be lost if he were deprived of the revenues from tobacco taxes. There will also be echoes of the way in which the Church of England was frequently criticized, before and after the war, for collecting ground rents on houses in London which were known to be used as brothels. The truth is that in a competitive economy it is exceedingly difficult to demand that respected institutions should exercise restraint about investment which others are entitled to ignore, and for practical purposes, of course, few people would object if Columbia were now seeking to make a fortune out of speculation in tobacco stocks. It has exposed itself to criticism only because it has set up what could easily become an intolerable conflict of interest. People will now be tempted to suppose that Columbia in its wisdom has decided that the probable connexion between smoking and lung cancer is illusory. At the press conference last week, Dr Kirk seems to have acknowledged, ineffectually perhaps, that his announcement was not to be taken as a pronouncement that smoking, after all, is safe. He and his colleagues will have to go much further than this if they are to remove the false impression which will have been created by the link between Columbia and the filter-and if they are to conform with the tough new spirit of the regulations of the Federal Trade Commission on tobacco advertising. The trouble, of course, is that if Columbia now embarks, as it should, on a campaign to inform tobacco smokers that there is no evidence that filters bring immunity from lung cancer, it will be undermining the chances of commercial success for its new enterprise. 